\section{Comparing Fumigant Retention of Polyethylene Mulches for Nutsedge Control in Florida Spodosols}

\author{
Bielinski M. Santos ${ }^{1,4}$, James P. Gilreath ${ }^{2}$, and Myriam N. Siham ${ }^{3}$
}

AdDITIONAL INDEX wORDs. Cyperus rotundus, Cyperus esculentus, methyl bromide, soil-borne pests, weeds, virtually impermeable film, metallized mulch

Summary. Although methyl bromide (MBr) has been phased out in developed countries, limited amounts will still be available in the United States for the next few years through critical-use exemptions. Therefore, production practices reducing $\mathrm{MBr}$ use are desirable from the grower and environmental standpoints. Fumigation efficacy depends on the duration of fumigants in the soil and mulch permeability; thus, field trials were conducted to compare $\mathrm{MBr}$ retention of low- and high-density polyethylene (LDPE and HDPE respectively) mulches with seven metallized mulches and virtually impermeable films (VIF) from different manufacturers, and to assess the effect of MBr retention on nutsedge (Cyperus rotundus and C. esculentus) control with these mulches. The compared mulches were 1) white VIF; 2) black VIF; 3) white-on-black VIF; 4) cowound VIF, which has a clear nylon layer that covers the bed and is superimposed with a layer of black HDPE mulch; 5) metallized; 6) metallized heat trap with a black stripe on the bed center; 7) metallized with a black stripe on the bed center; 8) black LDPE mulch; and 9) black HDPE mulch. All treatments received $175 \mathrm{lb} /$ acre of $\mathrm{MBr}+$ chloropicrin $(\mathrm{Pic} ; 67: 33 \mathrm{v} / \mathrm{v})$. A nonfumigated control plot covered with LDPE mulch, and a treatment covered with HDPE mulch and fumigated with $350 \mathrm{lb} /$ acre of $\mathrm{MBr}+\mathrm{Pic}$ were also established. Nutsedge emergence through mulches increased rapidly beginning 18 days after treatment (DAT). Nutsedge populations at 28 DAT in the nonfumigated control covered with LDPE mulch had the greatest emergence $\left(88.8\right.$ plants $\left./ \mathrm{ft}^{2}\right)$, followed by LDPE and HDPE mulches with $175 \mathrm{lb} /$ acre of $\mathrm{MBr}+\operatorname{Pic}\left(67.0\right.$ plants $\left./ \mathrm{ft}^{2}\right)$, HDPE mulch with $350 \mathrm{lb} /$ acre of $\mathrm{MBr}+\operatorname{Pic}\left(25.0\right.$ plants $\left./ \mathrm{ft}^{2}\right)$, and VIF and metallized mulches with $175 \mathrm{lb} / \mathrm{acre}$ of $\mathrm{MBr}+\operatorname{Pic}\left(<2\right.$ plants $\left./ \mathrm{ft}^{2}\right)$. There were no significant differences in fumigant retention between the metallized mulches and VIF. These mulches retained 3.7 and 1.8 times more MBr than HDPE and LDPE mulches fumigated with 175 and $350 \mathrm{lb} /$ acre of $\mathrm{MBr}+\mathrm{Pic}$, respectively.

$\mathrm{P}$ olyethylene-mulched vegetables are planted on $\approx 70,000$ acres in Florida (Olson, 2004). One of the main problems in plasticulture is nutsedge control, because of its ability to penetrate through mulch films and to reduce crop yields severely. Previous research has indicated that nutsedge interference can reduce bell pepper (Capsicum annuum), tomato (Lycopersicon esculentum), radish (Raphanus sativus), and cilantro (Coriandrum sativum) yields by $22 \%, 51 \%, 100 \%$, and $61 \%$, respectively (Gilreath and Santos, 2005; Gilreath et al., 2005; Morales-Payan et al., 1997; Santos et al., 1998).

Gulf Coast Research and Education Center, IFAS, University of Florida, Wimauma, FL 33598

${ }^{1}$ Assistant Professor of Horticulture.

${ }^{2}$ Former Professor of Weed Science.

${ }^{3}$ Former Research Assistant.

${ }^{4}$ Corresponding author. E-mail: bmsantos@ufl.edu.
During the past 30 years, methyl bromide $(\mathrm{MBr})$ fumigation has effectively controlled nutsedge sprouting, thus reducing mulch perforation. In contrast, some of the most prominent $\mathrm{MBr}$ alternatives provide weak or inconsistent nutsedge control when compared with $\mathrm{MBr}$ (Chase et al., 2006). Furthermore, $\mathrm{MBr}$ has been phased out in developed countries in compliance with the agreements of the Montreal Protocol for ozonedepleting molecules (Hildebrand,
2004). Despite this, limited amounts of $\mathrm{MBr}$ will still be available in the United States through critical-use exemptions issued for situations in which no suitable alternatives have been widely accepted. Currently, the U.S. allocation for critical-use exemptions in all sectors of agriculture for 2006 is $32 \%$ of the baseline levels of 1991 (Florida Fruit and Vegetable Assn., 2006). Because of this process, and until proper alternatives are extensively used, limited $\mathrm{MBr}$ amounts will still be available for a few more years for vegetable crop production in Florida and California. As a consequence of depletion of existing stocks of $\mathrm{MBr}$, it is expected that its cost will increase. Therefore, production practices that reduce $\mathrm{MBr}$ use are desirable from the grower and environmental standpoints.

Polyethylene mulches are extensively used in vegetable and fruit crops, and ornamental nurseries for increased weed control, growth and yield, reduced nutrient leaching, and increased soil moisture retention. Some of the disadvantages of mulch use include the relatively high cost of disposal, difficulty of removal, and increased pesticide runoff (Brown and Channell-Butcher, 2001; Hochmuth, 1998; Lamont, 1993; Rice et al., 2001). Therefore, the decision of using polyethylene mulch is generally justified by feasible economic returns, which partially depend on effective pest management.

Yates et al. (2002) indicated that to improve the efficacy of a given fumigant, it was necessary to have a biologically active dose combined with a prolonged time of exposure. Using this principle, several researchers have shown that it is possible to reduce fumigant volatilization and rates without losing efficacy, such as 1,3-dichloropropene plus chloropicrin (Pic), when combined with a highly retentive mulch (Chase et al., 2006; Santos et al., 2006; Wang et al.,

\begin{tabular}{llll}
\hline $\begin{array}{l}\text { Units } \\
\begin{array}{l}\text { To convert U.S. to SI, } \\
\text { multiply by }\end{array}\end{array}$ & U.S. unit & SI unit & $\begin{array}{l}\text { To convert SI to U.S., } \\
\text { multiply by }\end{array}$ \\
\hline 0.4047 & $\mathrm{acre}(\mathrm{s})$ & $\mathrm{ha}$ & 2.4711 \\
29.5735 & $\mathrm{fl} \mathrm{oz}$ & $\mathrm{mL}$ & 0.0338 \\
0.3048 & $\mathrm{ft}$ & $\mathrm{m}$ & 3.2808 \\
0.0929 & $\mathrm{ft}^{2}$ & $\mathrm{~m}^{2}$ & 10.7639 \\
2.5400 & inch $(\mathrm{es})$ & $\mathrm{cm}$ & 0.3937 \\
1.1209 & $\mathrm{lb} / \mathrm{acre}$ & $\mathrm{kg} \cdot \mathrm{h}^{-1}$ & 0.8922 \\
1 & $\mathrm{ppm}$ & $\mu \mathrm{L} \cdot \mathrm{L}^{-1}$ & 1
\end{tabular}


2001). Previous studies showed that fumigant retention in the soil could be improved with virtually impermeable films (VIF), which consist of an impermeable layer of ethylene vinyl alcohol or polyamide in between polyethylene layers (Gilreath et al., 2004; Hochmuth et al., 2003; Yates et al., 2002). These films are less permeable to fumigants than either low-density polyethylene (LDPE) or high-density polyethylene (HDPE) mulches, which are extensively used in vegetable crops in Florida.

Another type of film is the metallized mulch, which is covered with a reflective aluminum-based coat on the surface. This type of film is also referred as "silver mulch" or "reflective mulch" in the literature and has been studied for its impact for repelling whiteflies and aphids (Csizinszky et al., 1997; Stapleton and Summers, 2002). Practices that can reduce $\mathrm{MBr}$ rates would diminish fumigant emissions and likely production costs. Therefore, the objectives of this study were to compare $\mathrm{MBr}$ retention of 2HDPE and metallized mulches and VIF, and to assess the effect of $\mathrm{MBr}$ retention on nutsedge control with mulches from different manufacturers.

\section{Materials and methods}

Two field studies were conducted during Summer and Fall 2004 in a commercial tomato production field located near Ruskin, Fla. The soil was a spodosol (siliceous, hyperthermic fine sand) with less than $2 \%$ of organic matter and a $\mathrm{pH}$ of 7.3 . The experimental site has a history of heavy infestation of the two nutsedge species in mixed stands. Planting beds were preformed with a standard bedder and were 32 inches wide on the base, 28 inches wide on the top, and 8 inches high. Beds were fumigated with $\mathrm{MBr}+\operatorname{Pic}(67: 33, \mathrm{v} / \mathrm{v})$ through three chisels spaced 12 inches apart, which delivered the fumigant 6 inches deep. Immediately after fumigation, beds were repressed, and drip irrigation lines and polyethylene mulches were placed on bed tops.

The compared mulches were 1) white VIF (Bromostop; Industrial Plastica Monregalise, Mondovi, Italy); 2) black VIF (Bromostop); 3) whiteon-black VIF (Bromostop); 4) cowound VIF (Hilex Poly Co., Hartsville, S.C.), which has a clear nylon layer that covers the bed and is superimposed by a layer of black HDPE mulch; 5) metallized (Canslit, Montreal); 6) metallized heat trap (Canslit) with a black stripe on the bed center; 7) metallized (Pliant Corp., Washington, Ga.) with a black stripe on the bed center; 8) black LDPE mulch (Pliant Corp.); and 9) black HDPE mulch (Hilex Poly Co.). All these treatments received $175 \mathrm{lb} / \mathrm{acre}$ of $\mathrm{MBr}+$ Pic. Additionally, a nonfumigated control plot covered with LDPE mulch, and a treatment with HDPE mulch fumigated with 350 $\mathrm{lb} /$ acre of $\mathrm{MBr}+\mathrm{Pic}$ were established. The latter is the current grower practice for the majority of tomato, bell pepper, and strawberry (Fragaria Xananassa) growers in Florida. These 11 treatments were distributed in a randomized complete block design with six replications.

Experimental units were a single 100 -ft-long row with a $10-\mathrm{ft}$ nontreated buffer zone at the end of each plot. Data values were collected on the central $50 \mathrm{ft}$. Nutsedge shoots that emerged through the mulches were counted at $18,28,35,47$, and $64 \mathrm{~d}$ after treatment (DAT). Methyl bromide retention was determined by taking two $100-\mathrm{mL}$ soil air samples per plot using sampling tubes (Gastec detector tubes no. $136 \mathrm{H}$; Gastec Corp., Ayase-City, Japan) at 4 inches deep and 8 inches away from bed shoulders at 1, 2, 4, and 6 DAT. Sample readings were averaged for each experimental unit.

Nutsedge emergence and fumigant retention data were analyzed with the general linear model procedure to determine treatments effects ( $P=0.05$; SAS Institute, Cary, N.C.). Preplanned orthogonal contrasts were performed to compare groups of mulches. A sigmoidal regression model $\left[\mathrm{y}=\mathrm{a}_{0} /\left(1+\mathrm{e}^{[-(\mathrm{x}-\mathrm{al}) / \mathrm{a} 2]}\right)\right]$ was used to characterize the

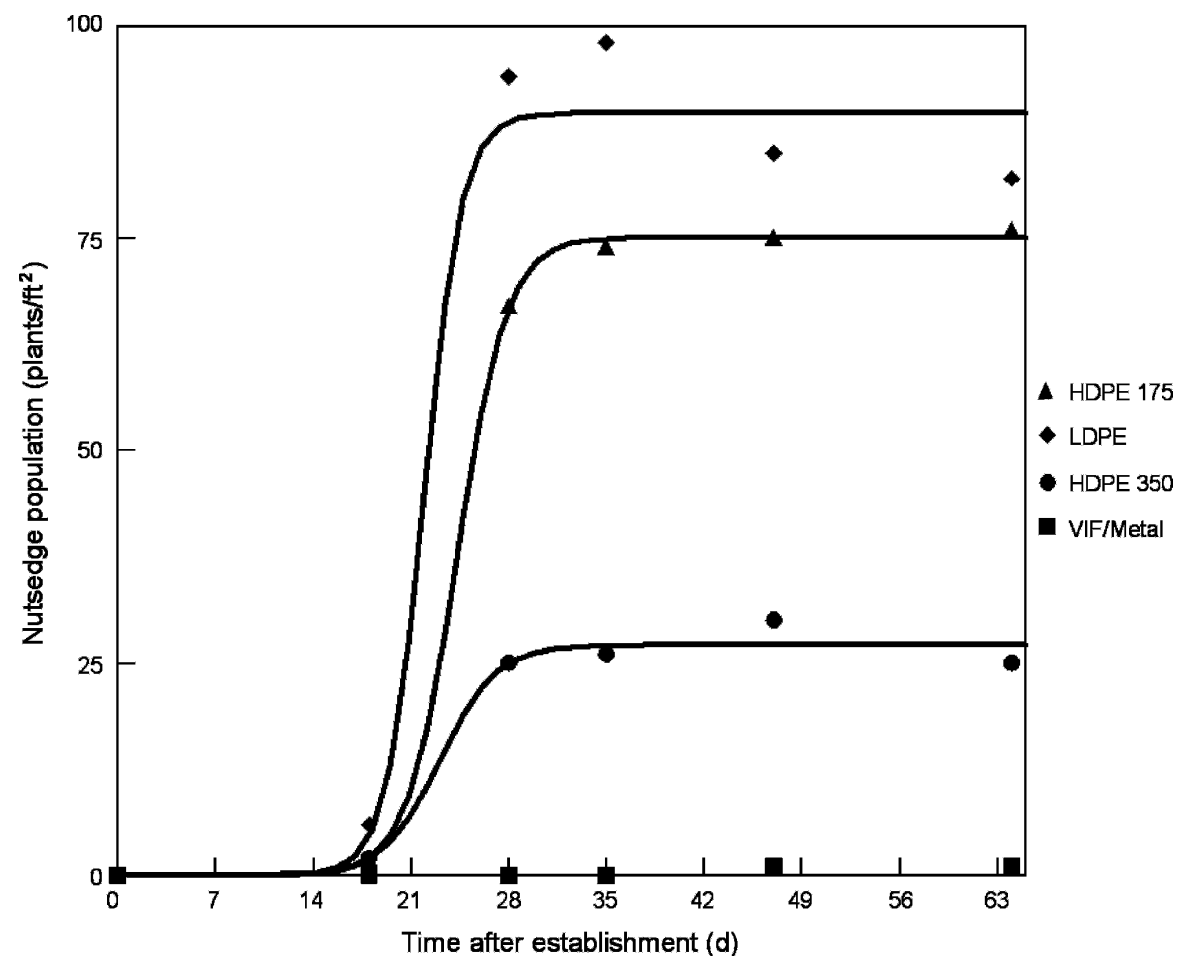

Fig. 1. Effects of combinations of mulches and methyl bromide + chloropicrin $(\mathrm{MBr}+\mathrm{Pic})$ rates and time after establishment on nutsedge emergence through films. Mulches and $\mathrm{MBr}+\mathrm{Pic}$ combinations are high-density polyethylene (HDPE) and low-density polyethylene (LDPE) mulch with $175 \mathrm{lb} /$ acre of $\mathrm{MBr}+\mathrm{Pic}$, a nonfumigated control covered with LDPE mulch, HDPE mulch with $350 \mathrm{lb} / \mathrm{acre}$ of $\mathrm{MBr}+\mathrm{Pic}$, and either virtually impermeable film (VIF) or metallized (Metal) mulch with $175 \mathrm{lb} /$ acre of $\mathrm{MBr}+$ Pic. Regression equations are $\mathrm{y}=75.12 /\left(1+\mathrm{e}^{[-(\mathrm{x}-24.27) / 1.77]}\right)$ for HDPE $/ \operatorname{LDPE} 175, \mathrm{y}=89.75 /\left(1+\mathrm{e}^{[-(\mathrm{x}-21.92) / 1.35]}\right)$ for the nonfumigated control, and $y=27.06 /\left(1+\mathrm{e}^{[-(\mathrm{x}-23.03) / 2.01]}\right)$ for HDPE 350 . There was no significant regression equation for VIF/Metal. All $v^{2}$ values were $\geq 0.90$. 1 plant $/ \mathrm{ft}^{2}=10.7639$ plants $/ \mathrm{m}^{2}, 1 \mathrm{lb} /$ acre $=1.1209 \mathrm{~kg} \cdot \mathrm{ha}^{-1}$. 
relationship between time after mulch establishment and nutsedge populations, and linear and quadratic regression models $\left(\mathrm{y}=\mathrm{a}_{0}+\mathrm{a}_{1} \mathrm{x}, \mathrm{y}=\mathrm{a}_{0}+\mathrm{a}_{1} \mathrm{x}+\right.$ $\mathrm{a}_{2} \mathrm{x}^{2}$ respectively) were used to describe the $\mathrm{MBr}$ retention of mulches at different times after fumigant application (SAS Institute).

\section{Results and discussion}

There were no significant studyby-treatment interactions, thus data from two studies were combined for analysis. Orthogonal comparisons of nutsedge populations among the 11 treatments revealed four distinctive groups of mulch-fumigant combinations consisting of 1 ) the LDPE and HDPE mulches with $175 \mathrm{lb} /$ acre of $\mathrm{MBr}+\mathrm{Pic}$, 2) all seven treatments with either VIF or metallized mulches with $175 \mathrm{lb} /$ acre of $\mathrm{MBr}+\mathrm{Pic}, 3)$ the HDPE mulch with $350 \mathrm{lb} /$ acre of $\mathrm{MBr}+\mathrm{Pic}$, and 4) the nonfumigated control covered with LDPE mulch (Fig. 1).

In all four cases, nutsedge emergence through mulches increased rapidly beginning at $18 \mathrm{DAT}$ and leveling off between 28 and 64 DAT. The highest nutsedge populations were found in the nonfumigated control plots covered with LDPE mulch. Based on the predicted values of the regression equations for this treatment, nutsedge densities increased from 4.7 plants $/ \mathrm{ft}^{2}$ at 18 DAT to 88.8 plants $/ \mathrm{ft}^{2}$ at $28 \mathrm{DAT}$, which indicate that the shoot emergence increased $\approx 19$ times in only $10 \mathrm{~d}$ (Fig. 1). In plots with HDPE mulch and fumigated with $175 \mathrm{lb} /$ acre of $\mathrm{MBr}+$ Pic, nutsedge densities increased from 2.1 to 67.0 plants/ $\mathrm{ft}^{2}$ from 18 to 28 DAT respectively. The latter nutsedge density was $\approx 25 \%$ less than the one obtained in the nonfumigated control plots at 28 DAT. Performance of HDPE mulch with $350 \mathrm{lb} /$ acre of $\mathrm{MBr}+\mathrm{Pic}$ against nutsedge emergence was relatively more satisfactory than the previous two groups of treatments, with nutsedge densities increasing from 2.0 to 25.0 plants $/ \mathrm{ft}^{2}$ from 18 to 28 DAT, representing about $72 \%$ less nutsedge emergence through the mulch than in the nonfumigated control plots. In contrast with all previous treatment groups, plots covered with either VIF or metallized mulches and fumigated with $175 \mathrm{lb} / \mathrm{acre}$ of $\mathrm{MBr}+\mathrm{Pic}$ resulted in nutsedge populations ranging from 0 to less than 2 plants/ $\mathrm{ft}^{2}$ up to 63 DAT (Fig. 1).

With regard to fumigant retention, there was no significant difference between plots covered with metallized mulches and VIF from different manufacturers, and data from these treatments were combined for analysis. Fumigant retention under metallized mulch and VIF decreased linearly as time after treatment establishment increased (Fig. 2). In contrast, $\mathrm{MBr}$ concentration under HDPE mulch with $350 \mathrm{lb} /$ acre of $\mathrm{MBr}+\mathrm{Pic}$, and the combination of either LDPE or HDPE mulches with $175 \mathrm{lb} /$ acre of $\mathrm{MBr}+\mathrm{Pic}$ declined quadratically. Based on the predicted values of the equations, all tested mulches had between 1378 and 1198 ppm of MBr at 1 DAT (Fig. $2)$. However, at $4 \mathrm{DAT}$, the predicted $\mathrm{MBr}$ retention under metallized mulches and VIF was 1177 ppm, which represented a $16 \%$ decrease compared with the concentration at 1 DAT. In the HDPE mulch treatments applied with 350 and $175 \mathrm{lb} /$ acre of $\mathrm{MBr}+\mathrm{Pic}$, the predicted fumigant concentration decreased by $58 \%$ and $73 \%$ (585 and $322 \mathrm{ppm}$ ) respectively at $4 \mathrm{DAT}$. In relative terms, soil under the VIF and metallized mulches had $\approx 3.7$ times more $\mathrm{MBr}$ than the soil applied with 175 $\mathrm{lb} /$ acre of $\mathrm{MBr}+\mathrm{Pic}$ and covered with either HDPE or LDPE mulches, and 1.8 times more fumigant than the soil applied with $350 \mathrm{lb} /$ acre of $\mathrm{MBr}$ + Pic and covered with HDPE mulch.

These data demonstrated that the superior retention properties of VIF and metallized mulches are greatly responsible for the improved nutsedge control in comparison with traditional LDPE and HDPE mulches used to cover tomato, bell pepper, and strawberry beds. It appears that the larger thickness and multilayer nature of VIF and metallized mulches in contrast with HDPE and LDPE mulches are major factors in reducing $\mathrm{MBr}$ volatilization, which in turn increases the duration of exposure of nutsedge reproductive structures to high fumigant concentrations, as suggested previously by multiple studies (Gilreath et al.,

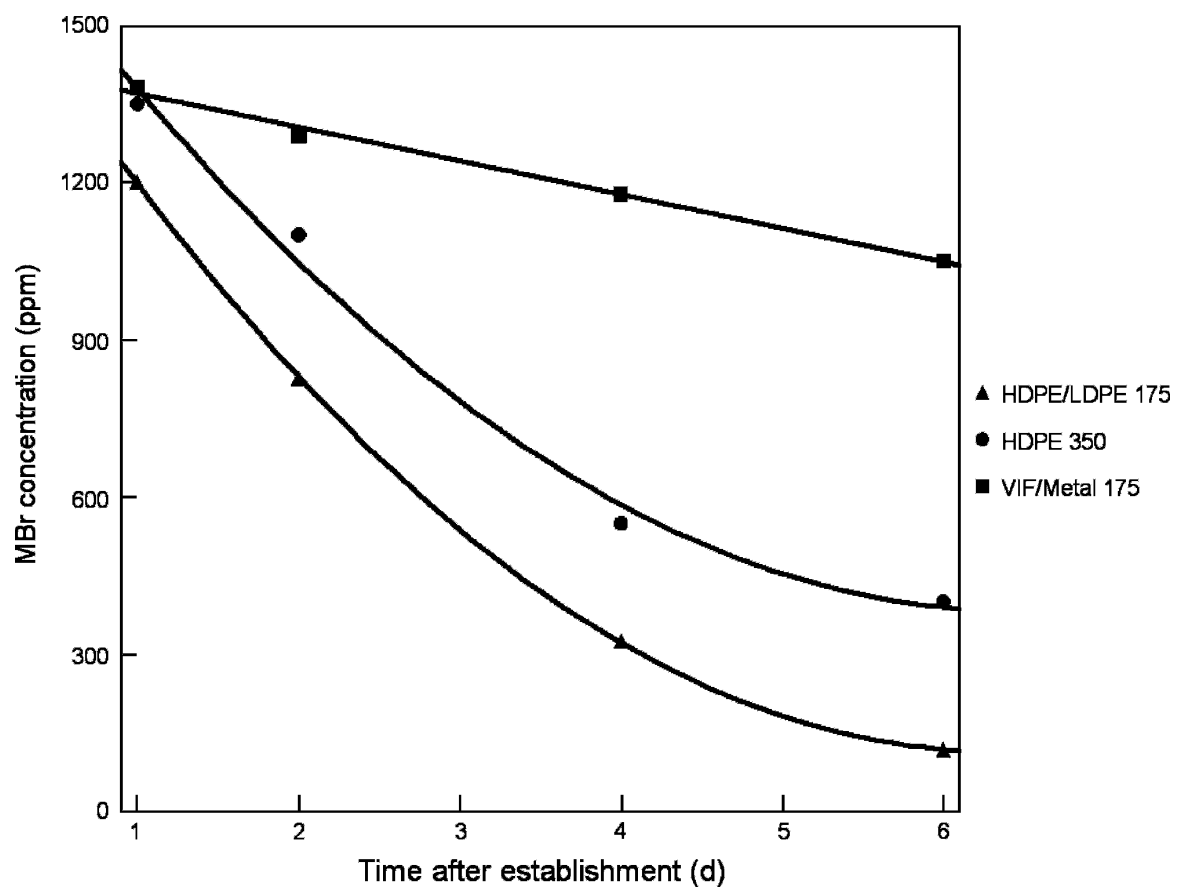

Fig. 2. Methyl bromide $(\mathrm{MBr})$ retention of different mulches over time. Mulches are high-density polyethylene (HDPE) mulch with 175 and $350 \mathrm{lb} /$ acre of $\mathrm{MBr}+$ chloropicrin (Pic), low-density polyethylene (LDPE) mulch with $175 \mathrm{lb} / \mathrm{acre}$ of $\mathrm{MBr}+\mathrm{Pic}$, and either virtually impermeable film (VIF) or metallized (Metal) mulch with $175 \mathrm{lb} /$ acre of $\mathrm{MBr}+$ Pic. Regression equations are $\mathrm{y}=1641.71-$ 482.21 $x+38.07 x^{2}$ for HDPE/LDPE 175, $y=1775.63-430.78 x+33.29 x^{2}$ for HDPE 350, and $\mathrm{y}=1434.10-64.34 \mathrm{x}$ for VIF/Metal. All $v^{2}$ values were $\geq 0.80 .1 \mathrm{ppm}=\mu \mathrm{L} \cdot \mathrm{L}^{-1}, 1 \mathrm{lb} /$ acre $=1.1209 \mathrm{~kg} \cdot \mathrm{ha}^{-1}$. 
2004; Hochmuth et al., 2003; Yates et al., 2002). Mulch texture, which includes thickness and stretching properties, should be considered because it might influence nutsedge penetration. In summary, this study showed that 1 ) one-half of the recommended $\mathrm{MBr}+\mathrm{Pic}$ rate of $350 \mathrm{lb} / \mathrm{acre}(175 \mathrm{lb} /$ acre) combined with VIF or metallized mulches provided superior control of nutsedge than the full fumigant rate with HDPE and 2) metallized mulches provided the same fumigant retention benefits and nutsedge control as VIF. From an economical standpoint, the higher cost of placing VIF or metallized mulches on beds in comparison with LDPE or HDPE mulches could be compensated by using only one-half the recommended $\mathrm{MBr}+\mathrm{Pic}$ rate and by improving nutsedge control, which in turn could translate into higher marketable yields.

\section{Literature cited}

Brown, J.E. and C. Channell-Butcher. 2001. Black plastic mulch and drip irrigation affect growth and performance of bell pepper. J. Veg. Crop Production 7:109-112.

Chase, C.A., W.M. Stall, E.H. Simonne, R.C. Hochmuth, M.D. Dukes, and A.W. Weiss. 2006. Nutsedge control with dripapplied 1,3-dichloropropene plus chloropicrin in a sandy soil. HortTechnology 16:641-648.

Csizinszky, A.A., D.J. Schuster, and J.B. Kring. 1997. Evaluation of color mulches and oil sprays for field and for the control of silver whitefly, Bemisia argentifolii (Bellows and Perring) on tomatoes. Crop Prot. 16:475-481.
Florida Fruit and Vegetable Assn. 2006. Annual report, 2006. 23 Dec. 2006. $<$ www.ffva.com/publications/ar.pdf $>$.

Gilreath, J.P., T.N. Motis, and B.M. Santos. 2005. Cyperus spp. control with reduced methyl bromide plus chloropicrin rates under virtually impermeable films in pepper. Crop Prot. 24:285-287.

Gilreath, J.P. and B.M. Santos. 2005. Efficacy of 1,3-dichloropropene plus chloropicrin in combination with herbicides on purple nutsedge (Cyperus rotun$d u s$ ) control in tomato. Weed Technol. 19:101-104.

Gilreath, J.P., B.M. Santos, T.M. Motis, and M. Van Hulten. 2004. Effect of mulch types on 1,3-dichloropropene + chloropicrin retention and nutsedge (Cyperus spp.) control. Proc. Fla. State Hort. Soc. 117:7-11.

Hildebrand, M.F. 2004. Summary of reports of the meeting of the parties to the Montreal Protocol on exemptions for the critical uses of methyl bromide for 2005 and 2006. Proc. 5th Intl. Conf. Alternatives Methyl Bromide 5:15-19.

Hochmuth, G. 1998. What to do with all that mulch? Amer. Veg. Grower 46:45.

Hochmuth, R.C., W.E. Davis, W.M. Stall, E.H. Simonne, A.W. Weiss, and J. Nance. 2003. Effect of 1,3-dichloropropene and chloropicrin on purple nutsedge (Cyperus rotondus $\mathrm{L}$.) control under two mulches and two application methods. Proc. Fla. State Hort. Soc. 116:164-167.

Lamont, W.J., Jr. 1993. Plastic mulches for the production of vegetable crops. HortTechnology 3:35-39.

Morales-Payan, J.P., B.M. Santos, and W.M. Stall. 1997. Effect of increasing purple nutsedge (Cyperus rotundus) densities on cilantro (Coriandrum sativum) yield. Proc. Fla. State Hort. Soc. 110:318-320.

Olson, S.M. 2004. Mulching, p. 27-30. In: S.M. Olson and E.H. Simonne (eds.). Vegetable production guide for Florida, 2003-2004. Inst. Food Agr. Sci. Publ., Univ. of Florida, Gainesville, Fla.

Rice, P.J., L.L. McConnell, L.P. Heighton, A.M. Sadeghi, A.R. Isensee, J.R. Teasdale, A.A. Abdul-Baki, J.A. Harmen-Fetcho, and C.J. Hapeman. 2001. Runoff loss of pesticides and soil: A comparison between vegetative mulch and plastic mulch in vegetable production systems. J. Environ. Qual. 30:18081821 .

Santos, B.M., J.P. Gilreath, T.N. Motis, M. von Hulten, and M.N. Siham. 2006. Effects of mulch types and concentrations of 1,3-dichloropropene plus chloropicrin on fumigant retention and nutsedge control. HortTechnology 16:637-640.

Santos, B.M., J.P. Morales-Payan, W.M. Stall, and T.A. Bewick. 1998. Influence of purple nutsedge (Cyperus rotundus) density and nitrogen rate on radish (Raphanus sativus) yield. Weed Sci. 46:661-664.

Stapleton, J.J. and C.G. Summers. 2002. Reflective mulches for management of aphids and aphid-borne virus disease in late-season cantaloupe (Cucumis melo L. var. cantalupensis). Crop Prot. 21: 891-898.

Wang, D., S.R. Yates, F.F. Ernst, and J.A. Knuteson. 2001. Volatilization of 1,3dichloropropene under different application methods. Water Air Soil Pollut. 127:109-123.

Yates, S.R., J. Gan, S.K. Papernik, R. Dungan, and D. Wang. 2002. Reducing fumigant emissions after soil application. Phytopathology 92:1344-1348. 